Accepting the correspondence between $\mathbf{X}$-ray density and density of the substance as a whole as a proof of the correctness of the dimensions of the unit cell in the micells, this would include speculative assumptions about the mutual distance of the chains in dry starch, about the differences between the mode of penetration of water on one hand, and of chloroform and petroleum ether on the other, about the mechanism of swelling of wet starch, etc. It would be outside the the mechanism of swelling of wet starch, etc. It would be out

cope of this communication to discuss these problems here. native stareh of the $B$-type is a primitive orthorhombic one with the above given dimensions.

We have not yet succeeded in flnding an arrangement of primary valency chains and water molecules in the cell that can account for the refiexion intensities and extinctions. In this connexion it is striking that $(0 k 0)$ is absent. Furthermore, it should be noted that the ratio of the axes $a$ and $c$ is $1: 1 \cdot 715$. Outlining a hexagonal cell as an orthorhombic one gives nearly the same ratio of axes $(1: 1 \cdot 73)$. As
the orthorhombic cell found is not centred in the basal plane, hexagonal symmetry, however, must be excluded.

Biological Section,

D. KREGER

Institute for X-Ray Investigation,

University College of Technology, Dune 15 .

t Kreger, D., Proc. Acad. Sci. Amsterdam, 48, 336 (1946).

Katz, J. R., et al., Z. physik. Chem., (A), 150, 37 (1930).

Strukturber., 3, 823 (1937)

"Strukturber., 3, "U23 (1937). (Leipzig, 1896), 65-68.

'Meyer, K. H., "Natural and Synthetic High Polymers"' (New York, 1942), $390^{\prime}$ and 406.

\section{Photosynthesis, Philosophy and Priestley}

THE recent demonstrations, by isotopic analysis ${ }^{1}$, that the oxygen evolved during green-plant photosynthesis is derived from decomposition of water has falsified what is perhaps the most widespread assumption in text-books. It has been all but universally taught that, because a green plant under the influence of sunlight takes in cerbon dioxide and evolves oxygen, the oxygen comes from decomposition of the oxide of carbon. The supposed reaction upon which this teaching is based may be given as

$$
\mathrm{CO}_{2} \rightarrow \mathrm{O}_{2}+\mathrm{C} \text {. }
$$

The philosophical interest of the persistence of this assumption is twofold: there was no sound evidence for it; and the other vital component in the photosynthetic process is neglected. G. Bredig in $1914^{2}$ was the first to suggest that photosynthetic oxygen came from water, but modern theory has arisen only since $1931^{3}$. Little participation of water in photosynthesis.

Absence of evidence is not, of course, a reason for not formulating an assumption. Teaching, however, has gone far beyond presenting the supposed course of photosynthesis as an assumption or hypothesis: the evolution of oxygen by decomposition of carbon dioxide has been repeatedly stated as a fact. In view of the importance of water in metabolism, and in promoting chemical change (including the formation of water itself), it is curious that a role for water in photosynthesis should have been uncritically rejected.

The common lecture-experiment of putting a green plant in water in a stoppered bottle, exposing it to sunlight and testing the evolved oxygen, scarcely leaves room for demonstration of the presence of an equivalent of earbon dioxide : whence does the carbon dioxide come?

Such experiments (as well as general knowledge which should suggest that a 'dry' photosynthetic reaction is inconceivable) denote guggest that a 'dry' photosynthetic reaction is inconceivable) denote
philosophic blunders for which it is difficult to find parallels. Apart from inattention to the source of the carbon dioxide, the seemingly from inattention to the source of the carbon dioxide, the seemingly obvious factor water is ignored. Writers of text-books are not infrequently responsible for perpetuation of ancient errors of fact, but it is fair to ask where in modern scientiflc history can be
striking example of preconception smothering facts.

striking example of preconception smothering facts.
M. W. Beijerinck ${ }^{4}$ discussed Joseph Priestley's work among that M. W. Beijerinck discussed Joseph Priestley's work among that
of microbiological pioneers who had investigated infusions ; otherwise of microbiological pioneers who had investigated infusions ; otherwise it seems to have been overlooked lately that Priestley was much interested by the frequent development of algæ (as we should say now) in extracts of organic matter after they had been exposed to air and sunlight. According to E. I. Rabinowitch ${ }^{8}$ an evolution of pure oxygen from algæ on the walls of insolated vessels containing water was called by Priestley "the most extraordinary of all my unexpected discoveries"; It seems rather remarkable that the chemical aspect of Priestley's work should have received almost exclusive attention. If more justice had been done to Priestley as biologist, it is possible that teaching about photosynthesis would have been on a more
philosophic basis. The indication by Kamen and Barker ${ }^{1}$ that atmospheric oxygen is probably of biological origin will enhance appreciation of Priestley's thought.

West of Scotland Agricultural College,

6 Blythswood Square Glasgow, C.2. July 5 .

${ }^{1}$ Ruben, S., Randall, M., Kamen, M. D., and Hyde, J. H., J. Amer. Chem. Soc., 63, 877 (1941). Vinogradov, A. P., and Teis, R. V., C.R. Acad. Sci. (U.R.S.S.), 33, 490 (1941). Dole, M., and Jenks, G., Science, 100, 409 (1944); Kamen, M. D., a
Proc. Nat. Acad. Sci., Washington, 31, 8 (1945).

Omschau, 18, 362 (1914).

' Umschau, 18, 362 (1914). 245 (1931). Van Niel, C. B., Adv., Rec. Traver. Bot. Neerland, 28, Jaarb. Kon. Akad. Wet. Amsterdam
Geschr. (Coll. Pap.), 5, 119 (1922).

"Photosynthesis and Related Processes", I (Interscience Publishers, Inc., New York, 1945).

\section{Antibacterial Substances in Water Extracts of Pure Forest Litter} IT was reported by Melin' that cold water extracts prepared from
single species litter of Swedish forest trees contain substances inhibiting single species litter of Swedish forest trees contain substances inhibiting
the growth of soil fungi. The fungi tested showed, however, pronounced differences in their sensitivity to the antibiotic agents present nounced differences in their sensitivity to the antibiotic agents present sensitive ones whereas the species inhabiting litter and causing its densitive ones whereas the species inhabiting litter and causing its filter does not seem to reduce the antibiotic activity, the growthinter does not seem to reduce the antibiotic activity, the growthequal to those exerted by the corresponding untreated extracts. On equal to those exerted by the corresponding untreated extracts. On autoclaving at a temperature of $120^{\circ} \mathrm{C}$. the antibiotic activity of the extracts made from litter of Acer platanoides L. and Fagus sylvatica L. was increased to a considerable degree. The antibiotic substances present in these extracts had a marked growth-inhibiting
on litter-decomposing and mycorrhiza-forming fungi.

In examining litter of a grass species, namely, Glyceria maxima (Hartm.) Holmb., for growth-affecting power, Melin ${ }^{1}$ found that cold water and hot water extracts of this material had no inhibitory effect on the fungi tested.

In view of the observations summarized above, it seemed of interest to examine whether forest litter extracts contained substances preventing the growth of pathogenic bacteria. Accordingly, cold water extracts were made from pure litter of the following species: Acer platanoides L., Betula verrucosa Ehrh., Fagus sylvatica L., Fraxinus excelsior L., Populus tremula L., Quercus robur L., and Vimus glabra

Huds. In addition,
was investigated.

The extracts tested were prepared as follows.

Air-dried and ground samples of single species litter were thoroughly mixed with distilled water in the proportion $1: 5$ and placed in a cold storage room at $4^{\circ} \mathrm{C}$. for $24 \mathrm{hr}$. In the case of Glyceria maxima one part of litter was extracted with six parts of distilled water. After passing through filter paper on a perforated Büchner funnel, each extract was divided into six portions. One portion, denoted by I, wartions, indicated by II-VI, were, before testing, treated according to the following scheme: II was saturated with chloroform; III was autoclaved; IV was passed through a Seitz filter: V was a Seitz flter and autoclaved.

The autoclaving was carried out for $15 \mathrm{~min}$. at a pressure of $1 \mathrm{kgm}$. per $\mathrm{cm}^{2}$, corresponding to a temperature of $120^{\circ} \mathrm{C}$.

The antibiotic power of the litter extracts thus prepared was tested against Staphylococcus aureus No. 266 by means of the cylinder plate method as described by Abraham et al. ${ }^{2}$ but with the modifications detailed by Wiken ${ }^{3}$. After fllling the cylinders with the solutions to be assayed, the plates were kept at room temperature for $2 \mathrm{hr}$. before placing at $37^{\circ} \mathrm{C}$.

TABLE 1. RESULTS OBTAINED IN TESTING UNDILUTED EXTRACTS OF SINGLE SPECIES LITTER FOR ANTIBIOTIO ACTIVITY AGAINST Staphylococcus aureus

\begin{tabular}{|l|c|c|c|c|c|c|}
\hline \multicolumn{1}{|c|}{ Species } & \multicolumn{6}{c|}{ Type of extract } \\
\cline { 2 - 7 } & I & II & III & IV & V & VI \\
\hline Acer platanoides & ++ & ++ & ++ & ++ & ++ & ++ \\
Betula verrucosa & 0 & 0 & 0 & 0 & 0 & 0 \\
Fagus syl"atica & 0 & 0 & 0 & 0 & 0 & 0 \\
Fraxinus excelsior & 0 & 0 & 0 & 0 & 0 & 0 \\
Populus tremula & 0 & 0 & 0 & 0 & 0 & 0 \\
Quercus robur & $0,+$ & 0 & + & 0 & + & + \\
Ulmus glabra & 0 & 0 & 0 & 0 & 0 & 0 \\
Glyceria maxima & 0 & 0 & 0 & 0 & 0 & 0 \\
& & & & & & \\
\end{tabular}

0 , no growth inhibition; + . mean diameter of disks of total growth inhibition $\approx 10 \mathrm{~mm}$.; ++, mean diameter of disks of total growth inhibition $\approx 20 \mathrm{~mm}$.

Some results obtained in assaying the extracts against Staphylococcus aureus are listed in Tables 1-3. It is evident that of the litter extracts tested only those of Acer platanoides and Quercus robur contain antibiotic agents effective against Staphylococcus under the conditions of the assay method used. The antibacterial activity of untreated cold water extracts (type I) obtained from various litter samples of Acer platanoides is rather high as compared to that of extracts made from litter of Quercus robur, the diameters of disks of complete growthinhibition produced by the former extracts being equal to or greater than $20 \mathrm{~mm}$. and those caused by the latter extracts amounting approximately to $10 \mathrm{~mm}$. Sometimes the quantities of antibiotic enough to be detected by means of the cylinder plate method.

TABLE 2. ANTIBIOTIC EFFECTS PRODUCED ON Staphylococcus aureus BY UNDILUTED LITTER EXTRACTS OF Acer platanoides AND Quercus robur

\begin{tabular}{|c|c|c|}
\hline \multirow{2}{*}{ Type of extract } & \multicolumn{2}{|c|}{ Species } \\
\cline { 2 - 3 } & Acer platanoides & Quercus robur \\
\hline I & $21 \cdot 1$ & 0 \\
II & $22 \cdot 4$ & 0 \\
II & $22 \cdot 1$ & $10 \cdot 3$ \\
V & $23 \cdot 6$ & 0 \\
VI & $22 \cdot 3$ & $10 \cdot 8$ \\
& $22 \cdot 2$ & $10 \cdot 6$ \\
\hline
\end{tabular}

The assay values (mm.) are means of 6 parallels. 